\title{
CardioRenal
}

Medicine

\section{The Association between Parathyroid Hormone Levels and the Cardiorenal Metabolic Syndrome in Non-Diabetic Chronic Kidney Disease}

\author{
Georges Saab ${ }^{a}$ Adam Whaley-Connell ${ }^{b}$ Andrew Bombeck ${ }^{c}$ \\ Manjula Kurella Tamura ${ }^{d}$ Suying $\mathrm{Li}^{\mathrm{e}}$ Shu-Cheng Chen ${ }^{\mathrm{e}}$ \\ Samy I. McFarlane ${ }^{f}$ James R. Sowers ${ }^{b}$ Keith Norris ${ }^{g, h}$ \\ George L. Bakris ${ }^{i}$ Peter A. McCullough ${ }^{j}$ \\ for the Kidney Early Evaluation Program Investigators
}

\begin{abstract}
${ }^{a}$ Washington University School of Medicine, St. Louis, Mo., ${ }^{b}$ Harry S. Truman VA Hospital, and University of Missouri-Columbia School of Medicine, Columbia, Mo., 'Division of Nephrology, Columbia University, New York, N.Y., d Division of Nephrology, Stanford University, Stanford, Calif., e KEEP Data Coordinating Center, Minneapolis Medical Research Foundation, Minneapolis, Minn., ${ }^{f}$ SUNY-Downstate Brooklyn, Brooklyn, N.Y., ${ }^{9}$ Charles R. Drew University of Medicine and Science, and havid Geffen School of Medicine, University of California, Los Angeles, Calif., 'University of Chicago School of Medicine, Chicago, Ill., and 'William Beaumont Hospital, Royal Oak, Mich., USA
\end{abstract}

\section{Key Words}

Chronic kidney disease $\cdot$ Hyperparathyroidism $\cdot$ KEEP $\cdot$ Metabolic syndrome

\begin{abstract}
Aims: The relationship between parathyroid hormone (PTH) and the cardiorenal metabolic syndrome was examined among non-diabetic persons with chronic kidney disease (CKD). Methods: In a cross-sectional analysis, the relationship between PTH levels and the cardiorenal metabolic syndrome was investigated in 3,215 non-diabetic participants in the National Kidney Foundation-Kidney Early Evaluation Program (KEEP 2.0) found to have CKD (eGFR <60 ml/ $\mathrm{min} / 1.73 \mathrm{~m}^{2}$ ). Results: In unadjusted analyses, the prevalence of the cardiorenal metabolic syndrome increased along increasing PTH quartiles $(31.7,33.8,37.3$, and $48.7 \%$, respectively, p for trend $<0.0001$ ). After multivariate adjustment, as compared to the first PTH quartile, odds of the cardiorenal metabolic syndrome were $16 \%(p=0.18), 35 \%(p=0.006)$, and $80 \%(p<0.0001)$ higher for the second, third, and fourth quartiles, respectively. When taken as a continuous predictor, each standard deviation increase of natural log transformed PTH was associated with
\end{abstract}




\section{CardioRenal \\ Medicine}

\begin{tabular}{l|l}
\hline Cardiorenal Med 2011;1:123-130 \\
\hline $\begin{array}{l}\text { DOl: 10.1159/000327149 } \\
\text { Published online: April 15, 2011 }\end{array}$ & $\begin{array}{l}\text { @ 2011 S. Karger AG, Basel } \\
\text { www.karger.com/crm }\end{array}$ \\
\hline Saab et al.: PTH and Cardiorenal Syndrome &
\end{tabular}

$26 \%(p<0.0001)$ higher odds of the cardiorenal metabolic syndrome. The association of PTH with the cardiorenal metabolic syndrome was not modified by age or gender ( $p$ for interaction was not significant for both modifiers). Conclusions: Among an outpatient non-diabetic population with CKD, higher PTH levels were associated with a higher prevalence of the cardiorenal metabolic syndrome.

Copyright $\odot 2011$ S. Karger AG, Basel

\section{Introduction}

The cardiorenal metabolic syndrome is associated with insulin resistance and is a risk factor for chronic kidney disease (CKD), independent of the presence of overt diabetes $[1,2]$. Furthermore, CKD is itself associated with development of insulin resistance [3-7] as evidenced by a greater incidence of diabetes in more advanced stages of CKD [8]. Mechanisms behind the association between CKD and insulin resistance (e.g. pre-diabetes) are likely multifactorial and include anemia [4], metabolic acidosis [6], vitamin D deficiency [3], as well as elevations of parathyroid hormone (PTH) (e.g. secondary hyperparathyroidism; 2HPT) [5, 7]. The presence of insulin resistance [9] has been described in early to moderately advanced CKD wherein anemia [10], metabolic acidosis, and even vitamin D deficiency [9] would not be expected to be as prevalent or severe. However, elevations in PTH can occur in early stages of CKD [11] and may contribute to insulin resistance.

Clinical studies in non-CKD populations $[12,13]$ suggest that elevations in PTH are associated with insulin resistance and impaired insulin release, reinforcing its independent role among patients with more advanced stages of CKD [5, 7]. Furthermore, among patients with advanced CKD, control of PTH with phosphate binders [5] or parathyroidectomy [7] may improve insulin secretion, further supporting a role for $2 \mathrm{HPT}$ in the progression of diabetes. While studies in non-CKD populations examining the association of PTH and prediabetes have provided conflicting results [14-17], less is known about this association in the general CKD population.

We sought to examine the association between increasing levels of PTH and the cardiorenal metabolic syndrome in pre-diabetic CKD participants in the Kidney Early Evaluation Program (KEEP 2.0) conducted by the National Kidney Foundation (NKF). The KEEP is a national screening program for CKD that represents a large, diverse CKD cohort with measures of PTH and both physical and biochemical components of the metabolic syndrome $[18,19]$.

\section{Methods}

Study Participants

KEEP recruitment methods and screening protocols have been described previously [18, 19]. Eligibility criteria included age $\geq 18$ years, a personal history of diabetes or hypertension, or a first-degree relative with kidney disease, diabetes, or hypertension. The KEEP database from November 1, 2005, to December 31,2007 , was examined. Participants found to have an eGFR $<60 \mathrm{ml} / \mathrm{min} / 1.73 \mathrm{~m}^{2}$ had additional testing for calcium, phosphorus, and intact PTH and were selected for inclusion. Patients with a history of diabetes were also excluded. The final study cohort included 3,215 participants.

Study Variables

Parathyroid Hormone. The intact PTH assay was performed using Immulite 2000 (Siemens Medical Solutions Diagnostics, Los Angeles, Calif., USA), a 2-site chemiluminescent enzyme-labeled immunometric assay. The intra-assay coefficient of variation was $4.2-5.7 \%$ and the inter-assay coefficient of variation ranged from 6.3 to $8.8 \%$. 


\section{CardioRenal \\ Medicine}

\begin{tabular}{l|l}
\hline Cardiorenal Med 2011;1:123-130 \\
\hline $\begin{array}{l}\text { DOI: 10.1159/000327149 } \\
\text { Published online: April 15, 2011 }\end{array}$ & $\begin{array}{l}\text { @ 2011 S. Karger AG, Basel } \\
\text { www.karger.com/crm }\end{array}$ \\
\hline
\end{tabular}

Saab et al.: PTH and Cardiorenal Syndrome

Definition of the Cardiorenal Metabolic Syndrome. The definitions included (1) pre-diabetes: a fasting blood glucose level $>100 \mathrm{mg} / \mathrm{dl}$ (ATP III criteria) without diabetes; (2) hypertension: average systolic blood pressure $>129 \mathrm{~mm} \mathrm{Hg}$ or diastolic blood pressure $>84 \mathrm{~mm} \mathrm{Hg}$ (ATP III criteria), or a self-reported history of hypertension, or treatment with blood pressure-lowering medication; (3) obesity: body mass index $\geq 30$ (WHO criteria); (4) dyslipidemia: triglyceride level $>150 \mathrm{mg} / \mathrm{dl}$ (ATP III criteria) or cholesterol $>200$ $\mathrm{mg} / \mathrm{dl}$, and (5) proteinuria: albumin to creatinine ratio $>29 \mathrm{mg} / \mathrm{g}$ (WHO criteria). Participants with three or more components were defined as having the metabolic syndrome.

Other Laboratory Measurements and Patient Characteristics. Age, sex, race, education, health insurance coverage, and timing of last physician visit were defined by self-report. Diabetes was defined as selfreported drug treatment or increased blood glucose, defined as a glucose level of $\geq 126 \mathrm{mg} / \mathrm{dl}(\geq 7.0$ $\mathrm{mmol} / \mathrm{l})$ if fasting or $>200 \mathrm{mg} / \mathrm{dl}(\geq 11.1 \mathrm{mmol} / \mathrm{l})$ if non-fasting. Calcium and phosphorus levels were determined using the Architect c8000 (Abbott Laboratories, Abbott Park, Ill., USA) with Arsenazo-III (Stanbio Laboratory, Boerne, Tex., USA) dye for calcium and ammonium molybdate for phosphorus. Calcium levels were not corrected as albumin levels were not available in KEEP. eGFR was calculated by using the isotope dilution mass spectrometry-traceable 4-variable Modification of Diet in Renal Disease $(M D R D)$ Study equation: $\left(175 \times\left[\right.\right.$ serum creatinine $\left.(\mathrm{mg} / \mathrm{dl})^{-1.154}\right] \times$ [age $\left.\left.(\text { years })^{-0.203}\right]\right) \times(0.742$ for women) $\times$ (1.21 for African Americans), as previously described [20]. Proteinuria was defined as a spot urine albumin to creatinine ratio $\geq 30 \mathrm{mg} / \mathrm{g}$.

\section{Statistical Methods}

Univariate associations of clinical and demographic variables were compared across quartiles of PTH using ANOVA for continuous variables and the $\chi^{2}$ for categorical variables. PTH was found to be skewed and was natural log transformed when examined as a continuous predictor. Subsequently, multivariate logistic regression was used to evaluate the association between PTH (modeled both continuously and categorically across PTH quartiles) and the metabolic syndrome. An initial model was unadjusted. A second model was adjusted for age, sex, and race. The final model was adjusted for age, race, sex, diabetes, calcium, phosphorus, eGFR, high-school education (yes/no), health insurance coverage (yes/no), and seeing a physician in the past year (yes/no). Multiplicative interaction terms were used to assess effect modification for gender and age ( $\geq 60$ vs. $<60$ years) [16-17]. A $p$ value $<0.05$ was considered statistically significant.

\section{Results}

Baseline characteristics by PTH quartiles are depicted in table 1. Persons in the highest PTH quartile were older and more frequently male and black. Additionally, those in the highest quartile were less likely to have graduated high school and less likely to have seen a physician in the prior year. Smoking and reported health insurance coverage were similar across quartiles. With regard to the metabolic syndrome components, the prevalence of prediabetes or insulin resistance, obesity, hypertension, and albuminuria occurred more frequently across increasing PTH quartiles, while dyslipidemia remained the same. Overall, the prevalence of the cardiorenal metabolic syndrome increased across PTH quartiles (fig. 1).

In the fully adjusted model, as compared to the first PTH quartile, odds of the cardiorenal metabolic syndrome were $16 \%(\mathrm{p}=0.18), 35 \%(\mathrm{p}=0.006)$, and $89 \%(\mathrm{p}<0.0001)$ higher in the second, third, and fourth quartiles, respectively (table 2). When examining PTH as a continuous predictor, each standard deviation increase of natural log-transformed PTH was associated with $26 \%$ (95\% CI 16-37\%) higher odds of the metabolic syndrome. No significant interaction was seen for age or gender ( $\mathrm{p}$ for interaction was not significant for each modifier).

The NKF-KDOQI (Kidney Disease Outcomes Quality Initiative) guidelines define 2HPT by CKD stages: $>70 \mathrm{pg} / \mathrm{ml}$ in CKD stage $3,>110 \mathrm{pg} / \mathrm{ml}$ in CKD stage 4 , and $>300 \mathrm{pg} /$ $\mathrm{ml}$ in CKD stage 5 [21]. Using the guidelines, KEEP screening activities in this cohort detected $2 \mathrm{HPT}$ in $54.9 \%$ of participants with metabolic syndrome, compared to $44.9 \%$ of participants without metabolic syndrome $(\mathrm{p}<0.0001)$. 


\section{CardioRenal \\ Medicine}

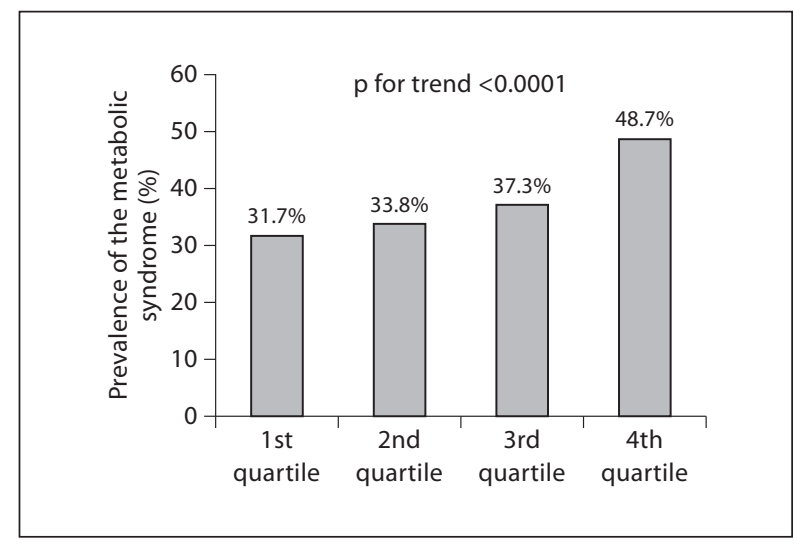

Fig. 1. Unadjusted prevalence of the cardiorenal metabolic syndrome across increasing PTH quartiles.

Table 1. Baseline demographic, clinical, and laboratory data by PTH quartiles

\begin{tabular}{|c|c|c|c|c|c|}
\hline & $\begin{array}{l}\text { 1st PTH quartile } \\
(3-48 \mathrm{pg} / \mathrm{ml}) \\
(\mathrm{n}=809)\end{array}$ & $\begin{array}{l}\text { 2nd PTH quartile } \\
(>48-70 \mathrm{pg} / \mathrm{ml}) \\
(\mathrm{n}=808)\end{array}$ & $\begin{array}{l}\text { 3rd PTH quartile } \\
(>70-101 \mathrm{pg} / \mathrm{ml}) \\
(\mathrm{n}=796)\end{array}$ & $\begin{array}{l}\text { 4th PTH quartile } \\
(>101-500 \mathrm{pg} / \mathrm{ml}) \\
(\mathrm{n}=802)\end{array}$ & $\begin{array}{l}\mathrm{p} \text { for } \\
\text { trend }\end{array}$ \\
\hline \multicolumn{6}{|l|}{ Demographics } \\
\hline Age, years & $66.0 \pm 12.5$ & $67.3 \pm 12.2$ & $69.0 \pm 11.5$ & $69.8 \pm 13.1$ & $<0.0001$ \\
\hline Age $>60$ years, $\%$ & 69.3 & 72.9 & 79.4 & 79.2 & $<0.0001$ \\
\hline Male, \% & 27.9 & 29.0 & 31.3 & 31.9 & 0.0248 \\
\hline Race, \% & & & & & $<0.0001$ \\
\hline White & 79.8 & 75.4 & 72.8 & 62.9 & \\
\hline Black & 11.4 & 13.5 & 19.6 & 27.4 & \\
\hline Other & 8.8 & 11.1 & 7.6 & 9.7 & \\
\hline Prior or current smoking, $\%$ & 40.5 & 40.5 & 38.2 & 40.6 & 0.3954 \\
\hline High-school education, $\%$ & 86.7 & 88.1 & 85.6 & 82.0 & 0.0016 \\
\hline Health insurance, $\%$ & 91.5 & 89.8 & 90.6 & 90.2 & 0.2518 \\
\hline Seen by physician in past year, $\%$ & 70.8 & 71.7 & 77.1 & 81.7 & $<0.0001$ \\
\hline \multicolumn{6}{|l|}{ Physical measurements } \\
\hline Systolic BP, mm Hg & $134.1 \pm 20.2$ & $136.1 \pm 19.5$ & $136.3 \pm 19.8$ & $137.1 \pm 20.2$ & 0.0213 \\
\hline Diastolic BP, mm Hg & $77.5 \pm 11.6$ & $78.3 \pm 11.5$ & $78.4 \pm 12.1$ & $78.6 \pm 12.5$ & 0.2957 \\
\hline Pulse pressure, $\mathrm{mm} \mathrm{Hg}$ & $56.7 \pm 17.1$ & $57.8 \pm 17.0$ & $58.0 \pm 16.8$ & $58.6 \pm 17.6$ & 0.1502 \\
\hline Body mass index & $28.5 \pm 5.9$ & $28.5 \pm 5.5$ & $28.8 \pm 5.5$ & $30.0 \pm 6.2$ & $<0.0001$ \\
\hline \multicolumn{6}{|l|}{ Laboratory parameters } \\
\hline Cholesterol, mg/dl & $201.8 \pm 40.8$ & $203.0 \pm 43.0$ & $201.4 \pm 41.4$ & $199.5 \pm 43.8$ & 0.4145 \\
\hline Triglycerides, mg/d & $166.9 \pm 96.8$ & $170.0 \pm 99.4$ & $164.5 \pm 102.4$ & $165.1 \pm 93.7$ & 0.6724 \\
\hline $\mathrm{eGFR}, \mathrm{ml} / \mathrm{min} / 1.73 \mathrm{~m}^{2}$ & $51.0 \pm 7.9$ & $51.1 \pm 7.9$ & $49.8 \pm 8.1$ & $44.6 \pm 11.5$ & $<0.0001$ \\
\hline \multicolumn{6}{|l|}{ Metabolic syndrome components } \\
\hline Dysglycemia, \% & 9.9 & 8.7 & 10.8 & 12.1 & 0.0365 \\
\hline Hypertension, \% & 84.9 & 87.8 & 90.1 & 93.2 & $<0.0001$ \\
\hline Obesity, \% & 33.0 & 32.1 & 36.2 & 44.4 & $<0.0001$ \\
\hline Dyslipidemia, \% & 69.6 & 69.2 & 66.3 & 70.4 & 0.4725 \\
\hline Proteinuria, $\%$ & 11.6 & 13.7 & 17.9 & 28.9 & $<0.0001$ \\
\hline Cardiorenal metabolic syndrome, $\%$ & 31.7 & 33.8 & 37.3 & 48.7 & $<0.0001$ \\
\hline
\end{tabular}




\section{CardioRenal \\ Medicine}

Cardiorenal Med 2011;1:123-130

\begin{tabular}{l|l}
\hline DOl: 10.1159/000327149 & $\begin{array}{l}\odot \text { 2011 S. Karger AG, Basel } \\
\text { www.karger.com/crm }\end{array}$ \\
\hline Published online: April 15, 2011 & \\
\hline
\end{tabular}

Saab et al.: PTH and Cardiorenal Syndrome

Table 2. The association between PTH and the cardiorenal metabolic syndrome

\begin{tabular}{llllc}
\hline & & Odds ratio & $95 \% \mathrm{CI}$ & p value \\
\hline Model 1 & 1st PTH quartile (ref.) & 1.00 & & \\
& 2nd PTH quartile & 1.10 & $0.90-1.36$ & 0.36 \\
& 3rd PTH quartile & 1.29 & $1.05-1.58$ & 0.02 \\
& 4th PTH quartile & 2.05 & $1.67-2.52$ & $<0.0001$ \\
\hline Model 2 & 1st PTH quartile (ref.) & 1.00 & & \\
& 2nd PTH quartile & 1.13 & $0.93-1.39$ & 0.22 \\
& 3rd PTH quartile & 1.36 & $1.10-1.68$ & 0.005 \\
& 4th PTH quartile & 2.19 & $1.78-2.70$ & $<0.0001$ \\
\hline Model 3 & 1st PTH quartile (ref.) & 1.00 & & \\
& 2nd PTH quartile & 1.16 & $0.93-1.43$ & 0.18 \\
& 3rd PTH quartile & 1.35 & $1.09-1.67$ & 0.006 \\
& 4th PTH quartile & 1.89 & $1.51-2.36$ & $<0.0001$ \\
\hline
\end{tabular}

Model 1: unadjusted; model 2: adjusted for age, race, and gender; model 3: adjusted for age, race, gender, smoking, alcohol use, eGFR, calcium, phosphorus, high-school education (yes/no), health insurance coverage (yes/no), and seeing a physician in the past year (yes/no).

\section{Discussion}

Our study demonstrates that increasing PTH levels are associated with an increased prevalence of the metabolic syndrome among non-diabetic participants with CKD in the NKF-KEEP. Our findings extend data from non-CKD populations wherein insulin resistance has been reported among persons with primary hyperparathyroidism [13] as well as data in more advanced stages of CKD wherein surgical or medical correction of $2 \mathrm{HPT}$ improves glycemic control $[5,7]$. Thereby, our data support the premise that higher PTH levels in CKD are associated with insulin resistance and pre-diabetes, and more likely presence of the metabolic syndrome. While the results of this study suggest that elevated PTH levels are associated with the cardiorenal metabolic syndrome in CKD, the cross-sectional nature and available measures in KEEP preclude determination of the mechanism behind this association.

Studies in non-CKD populations examining the association of PTH and pre-diabetes and the cardiorenal metabolic syndrome have provided conflicting results, with the largest studies suggesting an association only in older men $[16,17]$. While the reason why gender and age modifications occurred is not clear, the association in older men was seen only at extreme PTH levels comparable to the third and fourth quartiles in this study, suggesting that the higher PTH levels in CKD might explain the more uniform finding without gender or age modifications. The addition of elevated PTH levels in CKD [9] in this pre-diabetic population may also have contributed to the stronger association.

The association of PTH and the cardiorenal metabolic syndrome could alternatively be explained by vitamin D deficiency $[22,23]$. However, data from NHANES indicate that low 25-hydroxyvitamin D levels are confounded not only by obesity, but also by older age, African-American and Hispanic race, and female gender [24]. Vitamin D levels are decreased in obesity, possibly through increased sequestration in adipose tissue [25], leading to less vitamin D-mediated suppression of PTH release [26]. The association of vitamin D deficiency and insulin resistance and diabetes has been well documented [9, 27-29] and remains even 


\section{CardioRenal \\ Medicine}

\begin{tabular}{l|l}
\hline Cardiorenal Med 2011;1:123-130 \\
\hline $\begin{array}{l}\text { DOl: 10.1159/000327149 } \\
\text { Published online: April 15, 2011 }\end{array}$ & $\begin{array}{l}\text { @ 2011 S. Karger AG, Basel } \\
\text { www.karger.com/crm }\end{array}$ \\
\hline Saab et al.: PTH and Cardiorenal Syndrome &
\end{tabular}

after adjustment for anthropomorphic surrogates of adiposity, such as waist circumference [27]. However, when more sensitive measures of adiposity are used in statistical models, the association with vitamin $\mathrm{D}$ and insulin resistance is markedly attenuated and no longer significant [27]. Furthermore, studies among large diverse populations have suggested that overt vitamin D deficiency $(<15 \mathrm{ng} / \mathrm{ml})$ is uncommon in CKD and largely restricted to those with GFR $<30 \mathrm{ml} / \mathrm{min} / 1.73 \mathrm{~m}^{2}[29,30]$ who make up $<10 \%$ of the KEEP population with CKD [31]. Additionally, other studies have found that the association of PTH and the cardiorenal metabolic syndrome is independent of vitamin $\mathrm{D}[15,16]$. KEEP did not measure vitamin $\mathrm{D}$, and thus future studies among CKD patients measuring vitamin $\mathrm{D}$ are required to further address this issue. Another possible explanation is fetuin-A. Higher PTH is associated with higher fetuin-A, an inhibitor of vascular calcification. High fetuin-A levels are also associated with insulin resistance and higher risk for diabetes. The latter relationship may be mediated by adiponectin [32].

It is possible that the metabolic abnormalities associated with the metabolic syndrome may lead to PTH elevations. We have previously reported that obesity is associated with elevated PTH levels in KEEP [33]. As mentioned above, obesity may result in increased sequestration of vitamin D in adipose tissue, leading to higher PTH levels. Additionally, the adipocytokine leptin directly inhibits the $1 \alpha$-hydroxylase enzyme, leading to lower $1,25-\mathrm{OHD}_{3}$ $[34,35]$ upregulating PTH release. Data from the bariatric surgery literature have shown that morbidly obese individuals prior to bariatric surgery can manifest 2HPT, possibly due to vitamin D deficiency [36]. Furthermore, after surgery with repleted levels of 25- and 1,25-dihydroxyvitamin $\mathrm{D}$, a form of hyperparathyroidism due to vitamin $\mathrm{D}$ resistance can be observed, reinforcing the complicated relationship between PTH, vitamin D, and obesity [37].

In conclusion, our data support a strong association between $2 \mathrm{HPT}$ and the metabolic syndrome in pre-diabetic individuals with CKD. Limitations of this study include the crosssectional nature of this analysis, precluding determination of temporality and causality. Additionally, KEEP lacks measures of vitamin $\mathrm{D}$ and more accurate and/or sensitive measures of adiposity/body fat to fully evaluate the effects of PTH as an independent predictor of the metabolic syndrome. Finally, single measurements of PTH and other measures may have led to misclassification. In view of these findings, prospective studies examining the role of $2 \mathrm{HPT}$ on preventing the development of the metabolic syndrome are warranted.

\section{Acknowledgments}

A.W.-C. is supported by the Department of Veteran's Affairs Career Development Award-2. K.N. is supported by NIH grants RR026138, MD00182, and MD000103.

\section{Disclosure Statement}

The authors have no conflicts of interest.

\section{References}

1 Chen J, Muntner P, Hamm LL, Jones DW, Batuman V, Fonseca V, Whelton PK, He J: The metabolic syndrome and chronic kidney disease in US adults. Ann Intern Med 2004; 140:167-174.

2 Whaley-Connell A, Pavey BS, McCullough PA, Saab G, Li S, McFarlane SI, Chen SC, Vassalotti JA, Collins AJ, Bakris G, Sowers JR; KEEP Investigators: Dysglycemia predicts cardiovascular and kidney disease in the Kidney Early Evaluation Program. J Clin Hypertens 2010;12:51-58. 


\section{CardioRenal Medicine}

\begin{tabular}{l|l}
\hline Cardiorenal Med 2011;1:123-130 \\
\hline DOI: 10.1159/000327149 & $\begin{array}{l}\text { @) 2011 S. Karger AG, Basel } \\
\text { www.karger.com/crm }\end{array}$ \\
Published online: April 15, 2011 &
\end{tabular}

Saab et al.: PTH and Cardiorenal Syndrome

-3 Mak RH: Intravenous 1,25 dihydroxycholecalciferol corrects glucose intolerance in hemodialysis patients. Kidney Int 1992;41:1049-1054.

4 Mak RH: Correction of anemia by erythropoietin reverses insulin resistance and hyperinsulinemia in uremia. Am J Physiol Renal Physiol 1996;270:F839-F844.

5 Mak RH, Turner C, Haycock GB, Chantler C: Secondary hyperparathyroidism and glucose intolerance in children with uremia. Kidney Int Suppl 1983;16:S128-S133.

6 Mak RHK: Effect of metabolic acidosis on insulin action and secretion in uremia. Kidney Int 1998;54:603-607.

7 Mak RHK, Bettinelli A, Turner C, Haycock GB, Chantler C: The influence of hyperparathyroidism on glucose metabolism in uremia. J Clin Endocrinol Metab 1985;60:229-233.

8 Lorenzo C, Nath S, Hanley A, Abboud H, Gelfond J, Haffner S: Risk of type 2 diabetes among individuals with high and low glomerular filtration rates. Diabetologia 2009;52:1290-1297.

-9 Chonchol M, Scragg R: 25-Hydroxyvitamin D, insulin resistance, and kidney function in the Third National Health and Nutrition Examination Survey. Kidney Int 2006;71:134-139.

10 El-Achkar TM, Ohmit SE, McCullough PA, Crook ED, Brown WW, Grimm R, Bakris GL, Keane WF, Flack JM; Kidney Early Evaluation Program: Higher prevalence of anemia with diabetes mellitus in moderate kidney insufficiency: the Kidney Early Evaluation Program. Kidney Int 2005;67:1483-1488.

-11 Vassalotti JA, Uribarri J, Chen SC, Li S, Wang C, Collins AJ, Calvo MS, Whaley-Connell AT, McCullough PA, Norris KC; Kidney Early Evaluation Program Investigators: Trends in mineral metabolism: Kidney Early Evaluation Program (KEEP) and the National Health and Nutrition Examination Survey (NHANES) 1999-2004. Am J Kidney Dis 2008;51:S56-S68.

12 Chiu K, Chuang L, Lee N, Ryu J, McGullam J, Tsai G: Insulin sensitivity is inversely correlated with plasma intact parathyroid hormone level. Metabolism 2000;49:1501-1505.

13 Tassone F, Procopio M, Gianotti L, Visconti G, Pia A, Terzolo M, Borretta G: Insulin resistance is not coupled with defective insulin secretion in primary hyperparathyroidism. Diabet Med 2009;26:968-973.

- 14 Ahlström T, Hagström E, Larsson A, Rudberg C, Lind L, Hellman P: Correlation between plasma calcium, parathyroid hormone (PTH) and the metabolic syndrome (MetS) in a community-based cohort of men and women. Clin Endocrinol 2009;71:673-678.

-15 Hjelmesaeth J, Hofsø D, Aasheim ET, Jenssen T, Moan J, Hager H, Røislien J, Bollerslev J: Parathyroid hormone, but not vitamin $\mathrm{D}$, is associated with the metabolic syndrome in morbidly obese women and men: a cross-sectional study. Cardiovasc Diabetol 2009;8:7.

16 Reis JP, von Mühlen D, Kritz-Silverstein D, Wingard DL, Barrett-Connor E: Vitamin D, parathyroid hormone levels, and the prevalence of metabolic syndrome in community-dwelling older adults. Diabetes Care 2007;30:1549-1555.

17 Reis JP, von Mühlen D, Miller ER III: Relation of 25-hydroxyvitamin D and parathyroid hormone levels with metabolic syndrome among US adults. Eur J Endocrinol 2008;159:41-48.

18 Brown WW, Collins A, Chen SC, King K, Molony D, Gannon MR, Politoski G, Keane WF: Identification of persons at high risk for kidney disease via targeted screening: the NKF Kidney Early Evaluation Program. Kidney Int Suppl 2003;83:S50-S55.

19 Brown WW, Peters RM, Ohmit SE, Keane WF, Collins A, Chen SC, King K, Klag MJ, Molony DA, Flack JM: Early detection of kidney disease in community settings: the Kidney Early Evaluation Program (KEEP). Am J Kidney Dis 2003;42:22-35.

20 Stevens LA, Stoycheff N: Standardization of serum creatinine and estimated GFR in the Kidney Early Evaluation Program (KEEP). Am J Kidney Dis 2008;51:S77-S82.

-21 K/DOQI clinical practice guidelines for bone metabolism and disease in chronic kidney disease. Am J Kidney Dis 2003;42:S1-S201.

22 Ford E, Ajani U, McGuire L, Liu S: Concentrations of serum vitamin D and the metabolic syndrome among US adults. Diabetes Care 2005;28:1228-1230.

-23 Kayaniyil S, Vieth R, Retnakaran R, Knight JA, Qi Y, Gerstein HC, Perkins BA, Harris SB, Zinman B, Hanley AJ: Association of vitamin $\mathrm{D}$ with insulin resistance and beta-cell dysfunction in subjects at risk for type 2 diabetes. Diabetes Care 2010;33:1379-1381.

24 Martins D, Wolf M, Pan D, Zadshir A, Tareen N, Thadhani R, Felsenfeld A, Levine B, Mehrotra R, Norris K: Prevalence of cardiovascular risk factors and the serum levels of 25-hydroxyvitamin D in the United States: data from the Third National Health and Nutrition Examination Survey. Arch Intern Med 2007;167:1159-1165.

25 Wortsman J, Matsuoka LY, Chen TC, Lu Z, Holick MF: Decreased bioavailability of vitamin D in obesity. Am J Clin Nutr 2000;72:690-693.

26 Ritter CS, Armbrecht HJ, Slatopolsky E, Brown AJ: 25-Hydroxyvitamin D(3) suppresses PTH synthesis and secretion by bovine parathyroid cells. Kidney Int 2006;70:654-659.

-27 Cheng S, Massaro JM, Fox CS, Larson MG, Keyes MJ, McCabe EL, Robins SJ, O’Donnell CJ, Hoffmann U, Jacques PF, Booth SL, Vasan RS, Wolf M, Wang TJ: Adiposity, cardiometabolic risk, and vitamin D status: the Framingham Heart Study. Diabetes 2010;59:242-248.

28 Chiu KC, Chu A, Go VLW, Saad MF: Hypovitaminosis D is associated with insulin resistance and $\beta$ cell dysfunction. Am J Clin Nutr 2004;79:820-825.

-29 Snijder MB, van Dam RM, Visser M, Deeg DJ, Dekker JM, Bouter LM, Seidell JC, Lips P: Adiposity in relation to vitamin D status and parathyroid hormone levels: a population-based study in older men and women. J Clin Endocrinol Metab 2005;90:4119-4123. 


\section{CardioRenal \\ Medicine}

-30 Levin A, Bakris GL, Molitch M, Smulders M, Tian J, Williams LA, Andress DL: Prevalence of abnormal serum vitamin D, PTH, calcium, and phosphorus in patients with chronic kidney disease: results of the study to evaluate early kidney disease. Kidney Int 2006;71:31-38.

-31 Whaley-Connell AT, Sowers JR, Stevens LA, McFarlane SI, Shlipak MG, Norris KC, Chen SC, Qiu Y, Wang C, Li S, Vassalotti JA, Collins AJ; Kidney Early Evaluation Program Investigators: CKD in the United States: Kidney Early Evaluation Program (KEEP) and National Health and Nutrition Examination Survey (NHANES) 1999-2004. Am J Kidney Dis 2008;51:S13-S20.

- 32 Ix JH, Sharma K: Mechanisms linking obesity, chronic kidney disease, and fatty liver disease: the roles of fetuin-A, adiponectin, and AMPK. J Am Soc Nephrol 2010;21:406-412.

- 33 Saab G, Whaley-Connell A, McFarlane SI, Li S, Chen SC, Sowers JR, McCullough PA, Bakris GL; Kidney Early Evaluation Program Investigators: Obesity is associated with increased parathyroid hormone levels independent of glomerular filtration rate in chronic kidney disease. Metabolism 2010;59:385-389.

-34 Matsunuma A, Horiuchi N: Leptin attenuates gene expression for renal 25-hydroxyvitamin D3-1 $\alpha$-hydroxylase in mice via the long form of the leptin receptor. Arch Biochem Biophys 2007;463:118-127.

-35 Tsuji K, Maeda T, Kawane T, Matsunuma A, Horiuchi N: Leptin stimulates fibroblast growth factor 23 expression in bone and suppresses renal $1 \alpha, 25$-dihydroxyvitamin D synthesis in leptin-deficient ob/ob mice. J Bone Miner Res 2010; 25:1711-1723.

- 36 Ernst B, Thurnheer M, Schmid SM, Schultes B: Evidence for the necessity to systematically assess micronutrient status prior to bariatric surgery. Obes Surg 2009;19:66-73.

- 37 Zalesin KC, Miller WM, Nori Janosz KE, Yanez J, Krause K, Chengelis DL, McCullough PA: Controversies in vitamin D: deficiency and supplementation after Roux-en-Y gastric bypass surgery. Therapy 2007;4:561-574. 